\title{
Dampak adanya Kampung Warna-Warni Malang bagi perubahan sosial dan dinamika masyarakat setempat
}

\author{
B. F. Sanah, I. W. Nafisah, Alan Sigit Fibrianto \\ Universitas Negeri Malang, Jl. Semarang No. 5 Malang, Jawa Timur, Indonesia \\ *Penulis korespondensi, Surel: alan.sigit.fis@um.ac.id
}

Paper received: 01-04-2021; revised: 15-04-2021; accepted: 30-04-2021

\begin{abstract}
Social change becomes a necessity in people's life. Social change also has an impact on the dynamics of society. The existence of Colorful Village in Malang City also has an impact on social change and community dynamics. This study used a descriptive qualitative method. The data techniques used were interviews and observation. The research location was conducted in Jodipan Colorful Village, Malang City, East Java, Indonesia. The research informants selected were 7 informants from the traders who were the original inhabitants of the village. The results showed that the existence of Jodipan Colorful Village had a significant impact on the lives of the local community. The existing social change process is social change and desired social change. Where the community can feel the positive impact of the Jodipan Colorful Village. Over time, the existence of the village also has an influence on community dynamics, such as the use of technology and the development of community knowledge.
\end{abstract}

Keywords: social change; community dynamics

\begin{abstract}
Abstrak
Perubahan sosial menjadi sebuah keniscayaan dalam kehidupan masyarakat. Perubahan sosial turut memberikan dampak bagi dinamika masyarakat. Keberadaan Kampung Warna-Warni di Kota Malang turut memberikan dampak bagi perubahan sosial serta dinamika masyarakat. Penelitian ini menggunakan metode deskriptif kualitatif. Teknik data yang digunakan adalah wawancara dan observasi. Lokasi penelitian dilakukan di Kampung Warna-Warni Jodipan Kota Malang, Jawa Timur, Indonesia. Informan penelitian yang dipilih sebanyak 7 informan dari para pedagang yang merupakan penduduk asli kampung tersebut. Hasil penelitian menunjukkan bahwa keberadaan Kampung Warna-Warni Jodipan memberikan dampak yang signifikan bagi kehidupan masyarakat setempat. Proses perubahan sosial yang ada yaitu perubahan sosial dan perubahan sosial yang dikehendaki. Dimana masyarakat dapat merasakan dampak positif dari adanya Kampung WarnaWarni Jodipan. Seiring berjalannya waktu, keberadaan kampung tersebut juga memberikan pengaruh pada dinamika masyarakat, seperti pada penggunaan teknologi dan perkembangan ilmu pengetahuan masyarakat.
\end{abstract}

Kata kunci: perubahan sosial; dinamika masyarakat

\section{Pendahuluan}

Perubahan sosial merupakan suatu realita dalam kehidupan masyarakat. Masyarakat akan terus terdorong untuk melakukan perubahan. Seperti halnya perubahan sosial antar masyarakat di Kampung Warna-Warni Kota Malang. Perubahan sosial ini tentunya memberikan pengaruh terhadap dinamika masyarakatnya. Kampung yang dulunya terlihat kumuh, menjadi Kampung Warna-Warni yang dijadikan sebagai destinasi wisata yang menarik karena hasil inovasi dari Mahasiswa Jurusan Ilmu Komunikasi Universitas Muhammadiyah Malang dan berhasil mengubah kondisi kampung tersebut yang sebelumnya kumuh Wisatawan yang datang tidak hanya dari wilayah sekitar Malang, akan tetapi juga meluas hingga luar provinsi bahkan luar negeri. 
Kampung Warna-Warni yang kami jadikan sebagai lokasi penelitian menunjukkan bahwa telah terjadi perubahan sosial yang sangat signifikan dan berdampak pada kemajuan. Penelitian yang kami lakukan mengarah pada warga di kampung tersebut yang membuka warung di setiap rumahnya yang menurut kami telah terjadi perubahan sosial dan dinamika pada masyarakat tersebut. Hal ini sesuai dengan penelitian kami di lapangan yang menunjukkan bahwa adanya perubahan tersebut dapat menambah pendapatan mereka. Kemajuan tersebut dapat menekan angka pengangguran di Kampung Warna-Warni dan memberikan lapangan pekerjaan bagi ibu rumah tangga.

Dalam dinamika sosial masyarakat, manusia tentu selalu mengalami perubahan dalam kehidupannya. Masyarakat mendapat pengaruh sedikit banyak dari lingkungannya untuk mengalami perubahan. Karena kondisi lingkungan mereka akan selalu berubah dan secara realitas mereka harus mampu menggunakan segala sumber kekuatan dirinya untuk mengikuti perubahan yang ada. Dalam dinamika tersebut masyarakat saling melakukan interaksi, sehingga terjadi perkembangan dan perubahan yang dapat berlangsung cepat atau lambat. Bahkan dapat memberikan dampak baik ataupun buruk. Dalam dinamika yang terjadi masyarakat bisa mengalami perubahan yang progress maupun regress bagi dirinya. Kondisi tersebut tentunya akan mempengaruhi struktur maupun pola kehidupan sosial mereka.

Menurut Soerjono Soekanto, dinamika masyarakat merupakan perubahan sosial yang terjadi dalam masyarakat yang mengalami permasalahan. Permasalahan bisa dilakukan perorangan atau kelompok, akan tetapi yang pastinya dengan adanya dinamika masyarakat, keteraturan sosial dalam masyarakat tidak berjalan dengan semestinya. Permasalahan yang ada akan mendorong masyarakat untuk melakukan mobilitas atau pergerakan. Pergerakan atau perubahan tersebut perlu dilakukan agar tercipta masyarakat yang mampu menyesuaikan diri dengan lingkungan yang menuntutnya bergerak dan akan menciptakan keteraturan sosial.

Beberapa faktor yang mempengaruhi dinamika masyarakat, antara lain (1) Penyebaran informasi, meliputi pengaruh dan mekanisme media dalam menyampaikan pesan-pesan ataupun gagasan (pemikiran). (2) Modal, antara lain sumber daya manusia ataupun modal finansial. (3) Teknologi, suatu unsur dan sekaligus faktor yang cepat berubah sesuai dengan perkembangan ilmu pengetahuan. (4) Ideologi atau agama, keyakinan agama atau ideologi tertentu berpengaruh terhadap proses perubahan sosial. (5) Birokrasi, terutama berkaitan dengan berbagai kebijakan pemerintahan tertentu dalam membangun kekuasaannya. (6) Agen atau aktor, hal ini secara umum termasuk dalam modal sumber daya manusia, tetapi secara spesifik yang dimaksudkan adalah inisiatif-inisiatif individual dalam "mencari" kehidupan yang lebih baik (Salam dalam Tejokusumo, 2014).

Menurut Gillin, perubahan sosial merupakan variasi cara-cara hidup yang telah diterima baik karena perubahan kondisi geografis, kebudayaan material,komposisi penduduk, ideologi, maupun karena adanya difusi ataupun penemuan baru dalam masyarakat. Perubahan sosial budaya merupakan gejala berubahnya struktur sosial dan budaya yang terjadi dalam suatu masyarakat. Menurut Hirschman, kebosanan sebenarnya merupakan penyebab manusia mengalami perubahan. Manusia akan terus melakukan perubahan setiap saat untuk meningkatkan kehidupannya menjadi lebih baik.

Adanya dinamika masyarakat dapat memberikan dampak bagi struktur maupun pola perilaku mereka, baik itu memberikan progress (kemajuan) ataupun (kemunduran). 
Dikatakan progress apabila perubahan tersebut memberikan dampak positif dan kemudahan bagi masyarakat dalam memenuhi kebutuhan hidupnya. Adapun dikatakan mengalami progres apabila perubahan yang ada dapat membawa pengaruh yang kurang menguntungkan bagi masyarakatnya dan tidak memberikan suatu kemajuan.

Menurut Selo Soemardjan, faktor pendorong perubahan sosial terbagi menjadi 10 bagian, yakni (1) Penemuan baru, keinginan manusia untuk memenuhi kebutuhan hidupnya dengan suatu kemudahan akan mendorong mereka untuk menciptakan suatu penemuan yang baru dengan berbagai inovasi yang lebih efisien dan efektif sesuai perkembangan zaman. (2) Dinamika jumlah penduduk, pertambahan jumlah penduduk sangat mempengaruhi perubahan sosial terutama dalam struktur sosial dan pemenuhan kebutuhan dalam masyarakat. (3) Pertentangan atau konflik, masyarakat akan terus berlomba untuk menciptakan sesuatu yang lebih efisien dalam pemenuhan kebutuhannya. Hal itu akan menimbulkan konflik yang menyebabkan perubahan sosial karena perbedaan keinginan dan cara yang bervariasi dalam pemenuhan kebutuhan hidupnya. (4) Lingkungan alam, adanya fenomena alam maupun gejala atau pengaruh dari luar, seperti bencana dan peperangan. (5) Keterbukaan, masyarakat yang memiliki keterbukaan terhadap suatu perubahan akan membuka banyak peluang masuknya perubahan yang semakin lama semakin bisa diterima karena mengalami inovasi. (6) Keinginan untuk maju, seseorang tidak akan pernah puas terhadap pencapaiannya, mereka akan terus terdorong untuk memenuhi keinginannya, meningkatkan status sosialnya hingga dapat dipandang maju dari yang lainnya. (7) Pendidikan formal yang maju, pendidikan akan mendorong kemajuan pola pikir seseorang. Tentunya mereka akan berpikir lebih rasional dalam melakukan sesuatu dan akan mendorong mereka melakukan suatu perubahan sosial sesuai konsep yang telah mereka pelajari. (8) Orientasi ke masa depan, seseorang pasti akan berpikir rasionalitas terhadap kehidupannya di masa mendatang. Mereka akan terdorong untuk melakukan kemajuan yang dapat menguntungkannya hingga masa mendatang. (9) Akulturasi, adanya perpaduan dua budaya yang berlangsung lama dan terus menerus dapat menciptakan suatu perubahan sosial. (10) Asimilasi, perpaduan dua budaya yang terjadi terus menerus dapat memunculkan budaya baru.

Perubahan yang direncanakan atau perubahan yang dikehendaki merupakan perubahan yang terjadi secara terencana melalui suatu sistem untuk mencapai suatu perubahan tertentu (Soemardjan, 1991). Dalam artikel penelitian ini menggunakan teori AGIL yang dikemukakan oleh Talcott Parsons, yakni (A) Adaptation, cara beradaptasi dengan pemenuhan sandang, pangan, dan papan untuk bisa bertahan hidup. (G) Goal Attainment, cara yang ditempuh untuk mencapai suatu tujuan yang kemudian menghasilkan suatu output. (I) Integration, sebagai proses penyatuan suatu tatanan sosial dalam suatu kelompok. (L) Latent Pattern Maintenance and Tension Management, suatu sistem yang dapat dijadikan panduan yang jelas dalam rangka untuk memenuhi nilai-nilai yang ada dalam masyarakat (Sutrisno \& Putranto, 2005).

\section{Metode}

Penelitian ini menggunakan metode deskriptif kualitatif. Metodologi kualitatif merupakan prosedur dalam penelitian menghasilkan suatu data deskriptif dengan kata-kata atau lisan yang diamati dari seseorang atau perilakunya (Moleong, 2004). Teknik pengumpulan data yang digunakan adalah wawancara dan observasi. Lokasi penelitian ini dilakukan di Kampung Warna-Warni Jodipan Kota Malang, Jawa timur. Alasan peneliti melakukan penelitian tersebut dikarenakan perubahan lingkungan sangat berdampak besar pada dinamika masyarakat setempat. Penelitian dilakukan pada Kamis, 21 November 2019. 
Informan penelitian yang dipilih sebanyak 7 informan dari para pedagang yang merupakan penduduk asli kampung tersebut.

\section{Hasil dan Pembahasan}

Dalam hasil penelitian ini peneliti mendapatkan informasi dari wawancara narasumber terkait Kampung Warna-Warni Jodipan banyak perkembangan dan perubahan yang dirasakan warga tersebut. Berawal dari mahasiswa dari Universitas Muhammadiyah Malang yang berinisiatif mengubah kampung yang dulunya kumuh menjadi kampung yang bisa menarik wisatawan baik dari luar kota, dalam kota, dan bahkan luar negeri.

Awal mula dijadikan sebagai tempat wisata pada tahun 2016 berawal dari pengecatan di Kampung Jodipan pada bagian depan rumah dan atap rumah berlanjut ke Kampung Tridi yang kemudian keduanya dikenal dengan nama Kampung Warna-Warni. Terlihat dari luar bahwa ada keunikan dari kampung tersebut, sebelum pembangunannya selesai wisatawan sudah mulai berdatangan ke kampung tersebut. Warga kampung itu sangat tidak menyangka bahwa kampung mereka menarik perhatian wisatawan.

Menyikapi kehadirannya kampung wisata Jodipan dan Tridi ada warga ada yang awalnya merasa resah karena sebagian dari aktivitas hidupnya terganggu dengan keramaian yang ada di kampung mereka sendiri yaitu adanya wisatawan yang berkunjung untuk melihat keunikan yang ada di tempat itu,karena yang datang ke Jodipan dan Tridi dari berbagai kalangan. Tetapi ada warga yang merasa bahwa mereka senang dengan dihadirkannya kampung mereka sebagai tempat wisata.

Warga kampung Jodipan atau Tridi merasakan manfaat dan perubahan dengan dijadikannya kampung mereka sebagai tempat wisata, yaitu meningkatkan perekonomian, memperkenalkan kampung mereka ke banyak orang, dan menguntungkan warga sekitar. Anak muda yang berada di kampung itu juga ikut berkontribusi dalam menjaga kondisi kampung yang tetap aman, damai dan sejahtera.

Hadirnya kampung wisata juga menambahkan lapangan pekerjaan untuk ibuibu yang berada di kampung tersebut. Mereka memanfaatkan kehadiran wisatawan untuk berjualan atau berdagang di setiap rumah mereka, ibu-ibu tersebut menjual macam-macam produk baik itu dari produk makanan, minuman, atau kerajinan yang mereka buat sendiri. Ibuibu kampung itu merasa pendapatan mereka meningkat untuk penambahan biaya hidup mereka.

Seiring dengan berjalannya waktu juga banyak kampung lainnya yang tercipta membuat warga merasa resah dengan perlahan sepinya pengunjung. Kampung Tridi dan Jodipan yang awalnya ramai, tetapi di tahun ini keramaian yang terlihat hanya ada pada harihari besar tertentu saja. Tetapi warga tersebut tetap bersyukur bahwa kampung mereka masih tetap digemari para wisatawan.

Dari hasil yang kami dapatkan, kami mengaitkan hasil dan temuan-temuan penting tersebut dengan beberapa konsep yang dapat mendukung penelitian ini, yaitu konsep dinamika masyarakat, dan teori perubahan sosial progress-regress. Dinamika masyarakat merupakan perubahan sosial yang selalu terjadi di masyarakat, dimana menurut Salam (dalam Tejokusumo, 2014), dinamika masyarakat dipengaruhi oleh beberapa faktor. Berdasarkan faktor tersebut masyarakat Kampung Jodipan yang menjadi objek penelitian kami didasari 
oleh agen atau aktor yang berupa sumber daya manusia dimana perubahan yang terjadi dimulai oleh sekelompok mahasiswa Universitas Muhammadiyah Malang yang mempunyai inisiatif untuk mengubah kampung Jodipan yang awalnya kumuh menjadi kawasan penduduk yang lebih bersih hingga kemudian dijadikan objek wisata. Dimana mereka bersama-sama mengecat kawasan rumah mereka agar terlihat lebih cantik.

Dalam penelitian ini juga terdapat faktor perkembangan teknologi yang turut serta mempengaruhi dinamika masyarakat di kampung tersebut. Dengan perkembangan ilmu pengetahuan yang cepat menjadikan masyarakat mudah menyerap kehadiran sekelompok mahasiswa yang membawa suatu perubahan dengan memanfaatkan teknologi yang mudah diterima oleh masyarakat Kampung Jodipan. Adanya sumber daya manusia yang dapat menerima perubahan dengan baik, menjadi faktor penting adanya dinamika masyarakat. Sehingga kehidupan mereka menjadi lebih baik. Kesadaran akan perlunya perubahan menjadikan masyarakat mudah menerima perubahan yang dibawakan oleh Agent of Change dimana mereka terdorong untuk bekerja keras untuk memenuhi kebutuhan keluarganya. Adanya perubahan yang dibawakan, dapat menutupi angka pengangguran di wilayah tersebut.

Perubahan sosial progress tepat ditujukan pada masyarakat Kampung Jodipan yang kami teliti saat itu telah terjadi kemajuan dari adanya perubahan kondisi kampung Jodipan yang awalnya terlihat kumuh menjadi tampak lebih cantik dan bersih. Kemajuan tersebut dapat dilihat dari masyarakatnya yang memiliki kreativitas dengan membuat handicraft dan kemudian dijadikan souvenir bagi para pengunjung. Dengan kreativitas yang semakin berkembang, akan membangun sumber daya manusia yang lebih baik. Angka pengangguran di kampung tersebut semakin kecil, dimana semua penduduk baik pria maupun wanita bisa dipekerjakan untuk mengurus wisata Kampung Jodipan tersebut.

Berdasarkan penelitian ini, menggunakan teori sosiologi oleh Talcott Parsons yang dikenal dengan Teori AGIL. Pertama, Adaptation yang membahas adanya proses penyesuaian diri terhadap perubahan yang telah terjadi pada warga di Kampung Warna-Warni. Meski awalnya ada salah satu diantara warganya merasa risih akan kehadiran para wisatawan yang berkunjung ke kampung mereka hampir setiap hari. Namun seiring berjalannya waktu mereka mampu menyesuaikan diri di tengah perubahan yang ada demi tercukupinya kebutuhan hidup. Perubahan yang ada dapat memberikan suatu kemajuan yang menguntungkan. Apalagi mereka yang mau menerima perubahan akan mempermudah mereka beradaptasi.

Kedua, Goal Attainment yakni setelah mampu menyesuaikan diri, mereka cepat tanggap dengan membuka warung kecil-kecilan di depan rumah maupun di area kampung warnawarni. Dari usaha tersebut mereka mendapatkan output yang dapat dimanfaatkan dalam pemenuhan kebutuhan hidupnya. Ibu rumah tangga dapat mewujudkan kreativitas mereka dengan membuat souvenir yang dijual kepada para pengunjung sebagai tiket masuk ke Kampung Tridi. Ketiga, Integration yang mana dengan adanya adaptasi yang dilakukan terdapat penguatan integrasi warga di kampung tersebut. Sehingga terbentuk suatu tatanan sosial yang baik dalam masyarakat. Hubungan sosial di antara masyarakat dapat mempengaruhi kemajuan atau progress utamanya dalam bidang sosial.

Keempat Latent Pattern Maintenance and Tension Management, terdapat suatu sistem yang mengarahkan mereka melakukan suatu perubahan yang terstruktur. Seperti awalnya mahasiswa Universitas Muhammadiyah Malang yang mendatangi kepala Rukun Tetangga untuk menyampaikan tujuan mereka untuk mengubah kondisi lingkungan Kampung Warna- 
Warni yang kurang terawat menjadi lebih indah dipandang. Dari situ terjadi koordinasi antara ketiganya kemudian bersama-sama mengubah citra Kampung Warna-Warni menjadi lebih baik. Segala perubahan yang ada sudah terencana dengan baik. Dengan adanya sistem tersebut mereka dapat mewujudkan nilai-nilai yang telah diatur di lingkungannya.

Perubahan yang terjadi di kampung tersebut termasuk dalam perubahan sosial yang direncanakan. Melalui proses musyawarah antara mahasiswa Universitas Muhammadiyah Malang, ketua Rukun Tetangga dan melibatkan masyarakat setempat untuk mengubah kondisi kampung yang awalnya kumuh menjadi bersih. Transformasi ini merupakan bentuk perubahan sosial yang direncanakan. Masyarakat melakukan perubahan tersistem dengan kerjasama antara mahasiswa dan ketua Rukun Tetangga.

Perubahan sosial juga berkaitan dengan dinamika masyarakat salah satunya terjadi di kampung Warna-Warni. Disana masyarakat yang awalnya tidak memiliki pekerjaan, dengan dibuatnya Kampung Warna-Warni masyarakat berkesempatan membangun usaha sebagai penambah biaya hidup. Interaksi antara masyarakat disana semakin erat dan terbuka karena selalu diadakan kegiatan gotong royong setiap minggunya guna mempertahankan kebersihan, kenyamanan, dan keindahan kampungnya. Adanya peningkatan terhadap warga kampung tersebut untuk tetap menjaga hubungan sosial yang terjalin.

\section{Simpulan}

Dapat disimpulkan bahwa warga di Kampung Warna-Warni Jodipan mendapatkan hasil dari adanya perubahan dari kampung mereka yang awalnya hanya sebatas kampung untuk mereka huni sekarang menjadi tempat wisata yang sangat ramai dikunjungi oleh wisatawan dari berbagai daerah di Indonesia maupun manca Negara. Para warga di kampung jodipan banyak yang membuka usaha seperti berjualan makanan dan pernak pernik untuk oleh-oleh hal ini dapat membantu perekonomian keluarga mereka dengan membuka warung atau toko untuk berjualan di kampung tersebut yang notabenenya dulu adalah kampung kumuh. Dengan adanya kampung warna warni ini juga mampu menekan faktor pengangguran karena banyak anak muda desa jodipan yang sekarang bisa bekerja seperti menjadi tukang parkir, tour guide dan penjual tiket masuk, maka banyak manfaat yang dirasakan oleh warga. Hal ini juga termasuk dengan konsep dinamika masyarakat dari teori perubahan sosial progress bahwa kampung warna warni jodipan memiliki progress yang sangat besar untuk kemajuan perekonomian bagi warga Kampung Warna-Warni Jodipan. Dan warga Kampung Jodipan menjadi erat persaudaraan dan sosialnya dan saling membantu untuk membuat Kampung Jodipan. Perubahan sosial progress tepat ditujukan pada masyarakat Kampung Jodipan yang kami teliti saat itu. Dengan perkembangan dan dengan kreativitas yang semakin berkembang ini, akan membangun sumber daya manusia yang lebih baik. Dan dapat mengurangi angka pengangguran yang ada pada kampung tersebut khususnya Kampung Jodipan ini.

\section{Daftar Rujukan}

Baharuddin, B. (2015). Bentuk-Bentuk Perubahan Sosial Dan Kebudayaan. Al-Hikmah, 9(2), 180-205.

Moleong, L. J. (2004). Metodelogi penelitian. Bandung: Penerbit Remaja Rosdakarya.

Efianingrum, A. Bab V perubahan sosial dan pendidikan. Sosiologi Dan Antropologi Pendidikan, 157.

Soemardjan, S. (1991). Perubahan Sosial. Yogyakarta: Gadjah Mada University.

Sutrisno, S., \& Putranto, P. (2005). Teori-teori Kebudayaan. Yogyakarta: Kanisius.

Tejokusumo, B. (2014). Dinamika masyarakat sebagai sumber belajar ilmu pengetahuan sosial. Geo Edukasi, 3(1). 